\title{
The Effect of Methodology on Learning Vocabulary and Communication Skills in Iranian Young Learners: A Comparison between Audiolingual Method and Natural Approach
}

\author{
Afsaneh Rahimi Tehrani \\ University of Isfahan, Isfahan, Iran \\ Hossein Barati \\ English Department, University of Isfahan, Isfahan, Iran \\ Manijeh Youhanaee \\ English Department, University of Isfahan, Isfahan, Iran
}

\begin{abstract}
In countries in which English is learned as a foreign or as a second language, children's language education has been recognized as an important factor. The present study aims to investigate the progress of EFL young learners via the two methods of Audiolingual and Natural approach. The focus therefore is on the acquisition of English words and communicative skills in a certain period of time, and on the best method for improving communication in English for EFL young learners. The participants in this study were 40 Iranian female young learners aged between 7 and 9. They were chosen randomly from two elementary schools where English was taught as an extra-program subject. In one school, English was taught through Audiolingual method and in the other, via Natural approach. The final tests' scores of each group were analyzed to see the improvement of the young learner's vocabulary and communicative skills in each method. The results indicated that young learners' vocabulary learning and communication skills improved significantly in Natural approach compared in that of Audiolingual method.
\end{abstract}

Index Terms - audiolingual method, natural approach, young learners, vocabulary learning, communicative skills

\section{INTRODUCTION}

Since the English language has become the dominant international language, the importance of learning English has become more evident and hence teaching English has become more important. In the same way, teaching English to young learners (TEYL) has attracted many people in the last decades around the world, and therefore, English education has been increasingly practiced at the primary levels. Learning is among everyday experiences for everyone, but it is most obvious for young learners who acquire new behaviors, facts, languages, ideas and concepts very rapidly (Bartsch, Horvath, and Estes, 2003).

"While teaching English to young learners, a number of challenges occur most of which stem from the young learners' characteristics that are different from those of older ones" (Cameron, 2003). Therefore, considering the young learners' characteristics and also the language instruction is of utmost importance. Young learners tend to learn language more implicitly rather than explicitly (Cameron, 2001; Pinter, 2006; Slatterly and Willis, 2001). Recognizing meaningful messages is easy for them, but they cannot analyze the language as a system. Thus, presenting the language within 'meaningful contexts' is crucial while teaching English to young learners. In this way, language use will be reflected authentically (Cameron, 2001; Halliwell, 1992).

In contrast, recent research on young learners' course-books and materials used in foreign language classes shows the implementation of a variety of methodologies and teaching strategies that focus specifically on the acquisition of particular grammatical structures and sets of vocabulary items. (Cameron, 2003). This goes back in the history to around 50 years ago, from the time that Grammar-translation method was introduced, to Direct method, after that to Audiolingual method, to Cognitive code and a host of variations in each. Other methods have also been introduced to the field such as Silent way, Total Physical Response, Suggestopedia, Natural approach, etc. So, the problem is which of these methods is more beneficial in teaching English to young learners and which one motivates the learners more in their learning of English. 
The present study therefore aims to investigate the effect of two of the above methods, namely Audiolingual and Natural approach on the progress of Iranian EFL young learners in learning English. The focus here is on the acquisition of English words and communicative skills in a certain period of time.

The present study addresses the following questions:

1. Are Audiolingual method and Natural approach significantly different in the acquisition of English vocabulary for EFL young learners?

2. Do EFL young learners communicate better in English through Audiolingual method or Natural Approach?

\section{BACKGROUND OF THE STUDY}

\section{A. Audiolingual Method}

The Audio-lingual method, like the direct method, is also an oral approach. However, it is very different in that "rather than emphasizing vocabulary acquisition through exposure to its use in situations, the Audio-lingual method drills students in the use of grammatical sentence patterns" (Anggraeni, 2007, p.13). It was believed that to acquire the sentence patterns of the target language, conditioning can help learners to respond correctly to stimuli through shaping and reinforcement.

Larsen-Freeman (2000) provides some typical techniques which are closely associated with the Audio lingual Method:

(1)Dialogue memorization, (2) Backward Build-up (Expansion Drill), (3) Repetition drill, (4) Chain drill, (5) Singleslot Substitution drill, (6) Multiple-slot Substitution drill, (7) Transformation drill, (8) Question and Answer drill, (9) Use Minimal Pairs, (10) Complete the dialogue, (11) Grammar games.

Repetition as an important factor in learning a language is emphasized in many studies, especially regarding child language learning. "Child discourse at the early stages of language acquisition is extraordinarily repetitive in nature. Children often repeat a large number of utterances addressed to them (other-repetition); they also often repeat their own utterances (self-repetition). The role of repetition in language acquisition has been much-discussed in psychology, linguistics, and anthropology" (Huang, 2010, p.1).

Studies which consider other-repetition (often referred to as 'imitation'), emphasize the importance of the role that repetition has in learning vocabulary and syntax but they have shown inconsistent results. Some studies (Moerk, 1977; Stine and Bohannon, 1983; Tager-Flusberg and Calkins, 1990) have resulted in only a limited or maybe no role of repetition in linguistic development. Other studies, however, have reported that it can facilitate grammatical and lexical improvement (Corrigan, 1980; Snow, 1981, 1983; Kuczaj, 1982; Speidel and Nelson, 1989; Speidel and Herreshoff, 1989; Pe'rez-Pereira, 1994).

The contradictions that have been found among these studies might be the result of differences in methodology among them, as assumed by Pe'rez-Pereira (1994). It means that different definitions of imitation have been used in different studies. Some studies adopted a narrower definition of imitation and considered only exact and reduced imitations. These studies concluded that imitations have no influence or just a little influence on linguistic development. On the other hand, other studies adopted a broader definition and included modified and expanded repetitions as imitations. These studies supported the claim that imitations promote grammatical development.

In one study, Hebb (1961) gave 24 lists of nine digits to each participant in order to measure the effect of the regular repetition of a sequence on immediate serial recall. While the participants were not aware, a sequence was repeated every third trial, resulting in eight repetitions of that sequence while all other sequences were non-repeating. The results showed that the participants' performance improved with repetition. This 'learning through repetition' effect is well known (e.g., Cumming, Page, \& Norris, 2003; Hitch, Fastame, \& Flude, 2005 ;) and, importantly, has been shown irrespective of whether participants become aware of the repetition or not (Couture \& Tremblay, 2006; Hebb, 1961; McKelvie, 1987).

Finally, it is worth mentioning that the popularity of Audiolingual method did not last for a long time "because of its failure to teach long-term communicative proficiency. It was discovered later that language was not acquired through a process of habit-formation and over learning and it is not necessary to avoid errors at all costs" (Brown, 2007 ,p.112).

\section{B. Natural Approach}

In 1983, The Natural Approach was published by Krashen and Terrell, in which a comprehensive second language acquisition theory is combined with a curriculum for language classrooms. "Krashen and Terrell see communication as the primary function of language, and since their approach focuses on teaching communicative abilities, they refer to the Natural Approach as an example of a communicative approach" (Richards and Rodgers, 2001, p. 129). In this approach, the nature of language is described with emphasis on the meaning. For example, the importance of vocabulary is highly focused on, suggesting that a language is essentially its lexicon and only inconsequently the grammar. Krashen (1987) presents five hypotheses in second language acquisition:

1) The Acquisition- Learning Hypothesis: It makes a distinction between learning and acquisition (Krashen, 1985; VanPatten \& Williams, 2007; and Mitchell \& Miles, 2004). Acquisition takes place naturally without the learner being consciously aware of it. In learning, on the other hand, the learner is gaining explicit knowledge about and is working consciously with the language. An important part of this hypothesis is that the two systems are separate. 
2) The Monitor Hypothesis: It states again that learnt knowledge is not very useful (Mitchell \& Miles, 2004). Learning is just a monitor, or editor, and its function is to edit the acquired knowledge when the learner is producing language and even then the learnt knowledge is only useful in very restricted exercises when there is time to retrieve it.

3) The Natural Order Hypothesis: It claims that learners follow sequences in their acquisition of specific forms of the language; a phenomenon already noticed both in L1 and L2 research (Mitchell \& Miles, 2004).

4) The Input Hypothesis: It focuses on the input. The point made here is that humans acquire language only by receiving comprehensible input. Language must be slightly above the level of the learner to make the optimal learning environment, i.e., i+1.

5) The Affective Filter Hypothesis: This is mainly about the learner's inner state. To be receptive for the input leading to language acquisition it is important that the learner is relaxed and comfortable. On the other hand, learners in a stressful environment where they are forced to produce language before they are ready will have high affective filter, and the processing of input will be blocked (VanPatten \& Williams, 2007).

Input is an important part of Krashen's theory. It is through the comprehensible input that learners acquire the language. Many researches have been done on the importance of input on acquisition. In a study conducted by Rodrigoa, Krashen, and Gribbons (2004), fourth semester Spanish students, who were learning Spanish as a foreign language at the university level in the US, accepted to participate in two kinds of comprehensible-input based instruction. One of them was an extensive reading class, where assigned and self-selected reading was combined, and the other one, a 'Reading-Discussion" class that included both assigned reading and discussions. Regarding a check-list vocabulary test and a grammar test, the result of this study indicates that students in both classes outperformed those in a traditionally taught class in these two type of tests. The results confirm the efficacy of comprehensible-input based pedagogy at the intermediate level.

Reading texts which are at an appropriate level of difficulty can be a good method to receive high comprehensible input. Krashen believes that "those who read more in a second language perform higher on comprehension exams than those who read less. Language can be acquired through reading material that includes vocabulary and structure just a little bit beyond language learners' current level of competence, i.e., " $i+1$ " "(Krashen, 1993b). When the material is too far below their current ability, it will not be useful enough for their progress in language learning and when the material is well beyond their comprehension, it will overwhelm them and cause discouragement. Krashen relates his Input Hypothesis to reading in the following:

The reading hypothesis is a special case of the comprehensible input hypothesis. It claims that reading for meaning, especially free voluntary reading, is comprehensible input, and is the source of much of our competence in literacy, our reading ability, writing style, much of our vocabulary and spelling competence, and our ability to use and understand complex grammatical constructions. (Krashen, 2002c, P.5)

Krashen (1993b, 1994) especially supports extensive reading for pleasure, or free voluntary reading. Extensive reading can be defined as the reading of large amounts of material just for pleasure and information, in which the material is usually chosen by the students and is comprehensible to them. According to Sims (1996) the value of such reading may be summarized as follows:

1. Several studies suggest that more reading leads to greater literacy development; 2 . Students who participated in free reading programs outperformed children who were taught by traditional methods; 3 . People, who reported more free reading, read and wrote better than those who reported less free reading; 4. Language is too vast and complex to teach and learn one rule or item at a time, thus traditional instruction cannot account for literacy development; 5. Literacy development is quite possible without conscious learning or output (Sims, 1996, pp.22-23).

Furthermore, Krashen's affective filter hypothesis plays an important role in receiving comprehensible input and therefore, acquiring the language. "Affect came to be considered as a very important contributing factor to success in learning. Some even went so far as to stress that affect was more important than cognitive learner abilities because without, say, motivation to learn cognitive learner abilities would not even start to be engaged in the process of learning" (Mihaljević Djigunović, J., 2006, p.11)

Motivation, as one of the affective filters considered by Krashen, has been a controversial issue for a long time with researchers on second and foreign language learning (Brown, 2001; Dornyei, 2003; Gardner, 2000; ManolopoulouSergi, 2004; Ryan, \& Deci, 2000; and Skinner, \& Madden, 2009). All of these researches emphasized the importance of motivation in second language learning.

Self-confidence and anxiety also have attracted the attention of many researchers. The results of the study conducted by Gardner et al. (1997) showed that "anxiety was low in confident learners and they feel that they are able to do well, whereas less confident learners experience higher anxiety and feel that they lack the ability to perform well" (Gardner., Smythe, Brunet, 1977, p.22). Kitano (2001) investigated the anxiety of college learners of Japanese and reported a correlation between anxiety and self-perception in male students.

\section{Vocabulary Learning}

It is universally recognized that vocabulary learning is a fundamental component both of acquisition of one's native language and of learning a foreign language. Vocabulary learning has been researched extensively in different ways such as individual difference studies of young children's acquisition of words in their native language, older children's and adults' acquisition of words in a foreign language, and experimental studies of nonword learning. The latter method 
simulates learning new words in a controlled way, for instance, manipulating the structure or phonological features of the new "words" to be learned.

Baddeley, Gathercole, and Papagno (1998) proposed the mot influential theory of vocabulary learning. They claimed that "phonological short-term memory has a very important role in constructing representations of the phonological form of new words both in one's native language and in a foreign language" (Baddeley, Gathercole, Papagno, 1998, p. 65). Baddeley and colleagues (see also Gathercole \& Baddeley, 1993) based their claim on an extensive review of manifold research. This included correlational studies on young children's first language acquisition and experiments on children's learning of new names as well as on learning word pairs versus word-nonword pairs. It also included adult experiments on the effect of manipulations such as articulatory suppression, word length, and phonological similarity on learning nonwords or the vocabulary of a foreign language. Furthermore, they considered the performance of neuropsychological patients, children with disabilities, and polyglot adults. Converging evidence from those different sources led the authors to the generalization that new word learning is linked to "phonological memory skills." Subsequent studies (e.g., Duyck, Szmalec, Kemps, \& Vandierendonck, 2003; Gathercole, Service, Hitch, Adams, \& Martin, 1999; Masoura \& Gathercole, 1999; Palladino \& Cornoldi, 2004) also supported that conclusion.

A language consists of a huge amount of words and for a language teacher it is essential to recognize what words to focus on and also how to work with vocabulary learning. Word knowledge is a multifaceted matter, and what kind of knowledge is the aim for the training is also important to reflect on. Stahl (1999) sees the importance of vocabulary learning and puts it this way: "Our knowledge of words determines how we understand texts, define ourselves for others, and define the way we see the world. A richer vocabulary does not just mean that we know more words, but that we have more complex and exact ways of talking about the world, and of understanding the ways of thinking more complex thinkers see the world... The more words we know, the more distinctions we make about the world, the more clearly we see things in our world. We use words to think; the more words we know, the finer our understanding is about the world" (p.1).

Two aspects of vocabulary knowledge, i.e., size and depth have been separated in the field of vocabulary learning and teaching by researchers (Bogaards and Laufer, 2004; Haastrup and Henriksen, 2000; Milton, 2009; Read, 2000). However, Milton (2009) in reviewing a large number of studies, Measuring Second Language Vocabulary Acquisition, states that these two aspects are inseparable and they might be closely related.

The number of words that language learners know at a particular level of language proficiency is referred to as the size of vocabulary knowledge (Nation, 2001). Nassaji (2004) states that "one widely used measure to assess the size of vocabulary knowledge in the literature is Vocabulary Levels Test (VLT), which has a word meaning matching format and is composed of words representing different word-frequency levels, ranging from high-frequency (2000-word level) to low-frequency words (10,000-word level)" (p.87). Milton (2009) states that through these tests "we get believable and stable results and they have good content validity" (p. 11).

Depth of vocabulary knowledge is related to how well the language learner knows a word (Read, 1993, 2000). According to Nassaji (2004), researchers have indicated "the complexity and multi-dimensionality of word knowledge and have suggested that knowing a word well should mean more than knowing its individual meanings in particular contexts" (p. 112). A learner must know a variety of knowledge that associate with a word such as: knowledge of its pronunciation, register, spelling and stylistic and morphological features (Haastrup and Henriksen, 2000; Nation, 1990; Richards, 1976), knowledge of the word's syntactic and semantic relationships with other words in the language, including collocational meanings and knowledge of antonyms, synonyms, and hyponyms (Chapelle, 1994; Henriksen, 1999; Read, 2000). One measure which is used widely in assessing only some of these aspects is Word Associates Test (WAT) that was originally developed by Read (1993, 2000).

Learning vocabulary is easier for young learners than learning structures because they can relate words to tangible and immediate meanings but structures do not seem very useful to them. It is better for children to see and use the words in relevant contexts, so that the words will be fixed in their mind and in this way, a vocabulary network is built up to relate the newly learned words to other ones. Duffelmeyer and Duffelmeyer (1979) point out that "how the words are learned is very important because it affects how well they are really understood" (p.15). Knowledge obtained by the learner is often just the surface meaning of the word and the essential meaning of that is missing.

\section{Communicative Language Teaching}

The focus of language teaching in the past was mostly on the form of language rather than the meaning (Brumfit \& Johnson, 1979). However, "even complete mastery of grammatical forms does not guarantee using the target language effectively in communication" (Berns, 1984, p.56; Johnson, 1979, p.98). Therefore, Communicative Language Teaching (CLT) was developed with the purpose of developing the learners' communicative competence (Richards \& Rodgers, 1986).

The central characteristic of CLT is that "almost everything that is done is done with communicative intent" (LarsenFreeman cited in Rao 2002, p.81). Second language acquisition is an unconscious process of using language, not directly acquired by conscious learning (Krashen, 1985). So, "this is the responsibility of the teacher is to create a proper setting for students to practice and acquire English in the classroom through activities. But the main problem is that the class time is limited and how to use this limited time to improve students' language competence through communication is important" (Singh and Li, 2005, p.97). 
As Widdowson (1978) claimed "an overemphasis on grammar would make the learners decrease their communicative abilities" (p.12). For instance, teachers' detailed explanations and exercises of grammar in grammartranslation classes may lead the students to have little chance to communicate with language (Singh and Li, 2005, p.43). According to Littlewood (1981), many aspects of language learning happen only through natural processes, i.e., when the learner is learning the language for communication and using it as an ultimate goal. In addition, Snow (1996) believes that when the learner is involved actively in communication with language, he/she can learn more effectively.

Widdowson, (1978) states that "the students in developing countries still have difficulties in using the language both in spoken and written forms because they have been taught formal English for many years" (p.24). In order to understand Chinese students' perceptions of communicative and non-communicative activities in EFL classroom and the difficulties they perceived, Rao (2002) conducted a case study. The results of the questionnaire revealed that

Although the students liked many of the communicative activities done in the classroom, they liked the noncommunicative activities more. Items including communicative activities were based on student-to-student interaction with or without the teacher monitoring. Items about noncommunicative activities emphasized formal correctness included workbook type drills and practice exercises. Six of the ten non-communicative activities were liked by more than half of the students while four of the nine communicative activities were favored by most students. Chinese students started to feel independent in the classroom. Just one third of the students needed their teachers to explain everything to them. Apparently, nearly all of the students liked student-student interaction while only a few pupils stated that they like interacting with each other by moving around the classroom. Lack of motivation for communicative competence, traditional learning styles and habits, EFL learning situations, lack of funding, etc. were among the reasons that caused some difficulties for the participants to participate in the communicative activities.

As a result of the study, all of the students participated in this study are aware that there is no single best way to teach. They all know that they need a combination of communicative and non-communicative activities. As Thompson (1996) indicated that "English learning can be facilitated if teachers can develop their own locally appropriate version of the communicative approach" (p.36).

\section{Methodology}

\section{A. Participants}

The participants in this study were 40 female Iranian young learners aged between 7 to 9 , in grades 1,2 , and 3 of elementary school and beginners' in learning English. They were chosen randomly from two elementary schools in Isfahan where English was taught as an extra-program subject. In one school, English was taught through Audiolingual method and in the other, it was taught via Natural approach.

\section{B. Instrument}

The only instrument used in this study was the final test used at the end of the school year in each method. The final test in Natural approach consisted of 8 questions, in which 2 questions were "matching the pictures with the correct answer", 5 questions for "drawing and coloring", and 1 "multiple choice question" but the choices were pictures. The final test in Audiolingual method consisted of 18 multiple choice questions. There were 4 "wh-questions", 4 "Yes/No questions" and 8 "fill in the blank questions".

\section{Procedures}

I asked the teachers in each school to give me the test papers of twenty of their students randomly. I then classified the questions into vocabulary and communicative items based on the definitions of vocabulary and communicative tests provided before (see 2.3. and 2.4.). An expert then reviewed my categories and confirmed them. Table 3.1. represents the number of items in each test related to each of the above categories.

TABLE 3.1.

QUESTIONS AND THEIR RELATED CATEGORY IN EACH FINAL EXAM

\begin{tabular}{|l|l|l|l|}
\hline Teaching methodology & Vocabulary Questions & Communicative Questions & Both \\
\hline Natural approach & $1-\quad 7 \mathrm{a}, 7 \mathrm{~b}, 7 \mathrm{c}$ & - & $2-3-4-5-6-7 \mathrm{~d}, 7 \mathrm{e}-8$ \\
\hline Audiolingual method & $1-2-5-6-10-14-15-16$ & $3-4-7-8-9-11-12-13-17-18$ & - \\
\hline
\end{tabular}

As the above table shows, the final exam for Audiolingual method consisted the items which were either vocabulary or communicative. But in the final exam for Natural approach, the items were either vocabulary questions or both vocabulary and communicative questions. There was no item which could be considered as a communicative item. So, in analyzing the scores for vocabulary questions, the items related to both categories and vocabulary items grouped together and in analyzing communicative items, items related to both categories were used as communicative items.

Furthermore, I observed five full sessions of each class in each school to find out how the teachers employed each method in their teaching and also how the young learners used English while learning it.

\section{Results}


The data obtained through the scores of 20 young learners' final exams in each group were put into t-test analysis. After calculating the mean scores on the vocabulary questions and applying a t-test on them, the results indicated a significant difference for vocabulary acquisition between two groups. The results are represented in Table 4.1. below:

TABLE 4.1.

INDEPENDENT SAMPLES TEST FOR VOCABULARY ITEMS IN FINAL EXAMS IN EACH METHOD

\begin{tabular}{|c|c|c|c|c|c|c|c|c|}
\hline & & \multicolumn{2}{|c|}{$\begin{array}{l}\text { Levene's Test for } \\
\text { Equality of Variances }\end{array}$} & \multicolumn{5}{|c|}{ t-test for Equality of Means } \\
\hline & & $\mathrm{F}$ & Sig. & $\mathrm{t}$ & df & $\begin{array}{l}\text { Sig. (2- } \\
\text { tailed) }\end{array}$ & $\begin{array}{l}\text { Mean } \\
\text { Difference }\end{array}$ & $\begin{array}{l}\text { Std. Error } \\
\text { Difference }\end{array}$ \\
\hline vocabulary & $\begin{array}{l}\text { Equal variances assumed } \\
\text { Equal variances not } \\
\text { assumed }\end{array}$ & 27.655 & .000 & $\begin{array}{l}-5.878 \\
-5.878\end{array}$ & $\begin{array}{l}38 \\
19.526\end{array}$ & $\begin{array}{l}.000 \\
.000\end{array}$ & $\begin{array}{l}-5.82750 \\
-5.82750\end{array}$ & $\begin{array}{l}.99146 \\
.99146\end{array}$ \\
\hline
\end{tabular}

As indicated in the above table, there is a significant difference in the acquisition of vocabulary between two groups of this study $(\mathrm{t}=-5.878, \mathrm{df}=38, \mathrm{p}<\mathrm{o} .05)$. Young learners in Natural approach outperformed those in Audiolingual method in the acquisition of vocabulary.

Moreover, the mean scores of the 20 young learners in two groups on communicative questions in final exams were calculated and a t-test was run on the data. The results are presented in Table 4.2.:

TABLE 4.2

INDEPENDENT SAMPLES TEST FOR COMMUNICATIVE ITEMS IN FINAL EXAMS IN EACH METHOD

\begin{tabular}{|c|c|c|c|c|c|c|c|c|}
\hline & & \multicolumn{2}{|c|}{$\begin{array}{l}\text { Levene's Test for } \\
\text { Equality of Variances }\end{array}$} & \multicolumn{5}{|c|}{ t-test for Equality of Means } \\
\hline & & $\mathrm{F}$ & Sig. & $\mathrm{t}$ & df & $\begin{array}{l}\text { Sig. (2- } \\
\text { tailed) }\end{array}$ & $\begin{array}{l}\text { Mean } \\
\text { Difference }\end{array}$ & $\begin{array}{l}\text { Std. Error } \\
\text { Difference }\end{array}$ \\
\hline communicative & $\begin{array}{l}\text { Equal variances } \\
\text { assumed } \\
\text { Equal variances not } \\
\text { assumed }\end{array}$ & $4.688 \mathrm{E} 1$ & .000 & $\begin{array}{l}-4.571 \mathrm{E} 0 \\
-4.571 \mathrm{E} 0\end{array}$ & $\begin{array}{l}38 \\
1.988 \mathrm{E} 1\end{array}$ & $\begin{array}{l}.000 \\
.000\end{array}$ & $\begin{array}{l}-3.06500 \\
-3.06500\end{array}$ & $\begin{array}{l}.67059 \\
.67059\end{array}$ \\
\hline
\end{tabular}

As indicated in Table 4.2., the students in Natural approach outperformed those in Audiolingual method in communicative items $(\mathrm{t}=-4.571, \mathrm{df}=38, \mathrm{p}<0.05)$. Therefore, it can be concluded that EFL young learners acquire communicative skills significantly better when English is taught through Natural approach.

\section{DisCUSSION AND CONCLUSION}

As the results of this study indicate EFL young learners learning English vocabularies via Natural Approach outperform those leaning through Audiolingual Method (see 4.1.). The reason might be that unlike Audiolingual Method in which "vocabulary is kept to a minimum while the students are mastering the sound system and grammatical patterns" (Larsen Freeman, 2000, p.46), the emphasis of Natural Approach is "on the primacy of meaning. The importance of vocabulary is stressed " (Richards and Rodgers, 2001, p. 130).

The difference between teaching vocabulary through two methods of Audiolingual and Natural approach, as the observation of two groups show, is that in Audiolingual method, repetition of the new words is the key element in learning vocabularies but in Natural approach, the teacher is the input provider (in this case vocabularies) and the learners are not forced to use the new language until they feel ready. Some studies mentioned before (see 2.1) have reported that "grammatical and lexical development is facilitated through repetition" (Corrigan, 1980; Snow, 1981, 1983; Kuczaj, 1982; Speidel and Nelson, 1989; Speidel and Herreshoff, 1989; Pe'rez-Pereira, 1994). On the other hand, a number of studies have concluded that "imitation plays no role or only a limited role in linguistic development" (Moerk, 1977; Stine and Bohannon, 1983; Tager-Flusberg and Calkins, 1990). This is in line with the results obtained from this study. The improvement of young learners' vocabulary learning through repetition in Audiolingual method was not that much significant compared to their improvement in the natural way. Emphasizing the importance of input comprehensibility in SLA, Krashen and Terrell (1983) claim that:

Acquisition depends crucially on the input being comprehensible. And comprehensibility is dependent directly on the ability to recognize the meaning of key elements in the utterance. Thus, acquisition will not take place without comprehension of vocabulary (p. 155).

Furthermore, a significant difference was observed in communication between two groups. Young learners in Natural approach communicate better than those in Audiolingual method (see 4.3.). It is again in relation with the theory of language underlying Natural approach. Language is viewed as a vehicle for communicating meanings and messages. Hence Krashen and Terrell state that "acquisition can take place only when people understand messages in the target language" (Krashen and Terrell, 1983, p. 19). Although they have a communicative approach to language, "they view 
language learning, as do audiolingualists, as mastery of structures by stages” (Richards and Rodgers, 2001, p. 98). This is, in fact, based on Krashen's natural order hypothesis.

As Widdowson (1978) claimed "an overemphasis on grammar would lead preventing the learners from developing their communicative competence" (p.33) and teaching grammar through different techniques is the main aim of Audiolingual method. Its overemphasis on learning grammar rather than communication skills caused the young learners in this study to perform poorly in communication skills. However, the emphasis of Natural approach on communication caused the improvement of communication skills in young learners in this study. According to Krashen, "acquisition takes place when we understand the input-language that contains 'structure' that is 'a little beyond' our current stage "(Krashen, 1987, p. 21). The idea is that "'meaning' has priority over 'structure'. Language a little beyond current competence is facilitated, according to Krashen, by the use of extra-linguistic input, context and knowledge of the world" (Krashen, 1987, p. 21). According to Krashen's second stage of the input hypothesis, "we acquire by understanding language that contains structure a bit beyond our current level of competence $(i+1)$. This is done with the help of context or extra-linguistic information" (Krashen, 1987, p. 21).

The conclusion drawn from Krashen's five hypotheses in relation to this study is the acquisition of English vocabularies, as the most important part of Natural approach, by providing input to learners, not forcing them to produce the language until they feel ready to do that. In this way, learners acquire the language and it improves their communicative skills.

\section{REFERENCES}

[1] Anggraeni, p. (2007). Audiolingual teaching as an alternative method in teaching speaking at Semarang State University (Master's thesis, Semarang State University, Pemalang,Nigeria)

[2] Bartsch, K., Horvath, K., Estes, D. (2003). Young children's talk about learning events. Cognitive Development 18, $177-193$.

[3] Brown, H. D. (2001). Teaching by principles: an interactive approach to language pedagogy. (New York, Addison Wesley Longman).

[4] Brown, H.D. (2007). Principles of language learning and teaching (5th ed.). Pearson, Longman.

[5] Brumfit, C.J., \& Johnson, K. (1979). The Communicative Approach to Language Teaching. Hong Kong: Oxford University Press.

[6] Cameron, L. (2001). Teaching languages to young learners. Cambridge: Cambridge University Press.

[7] Cameron, L. (2003). Challenges for ELT from the expansion in teaching children. ELT Journal, 57(2), 105-112.

[8] Corrigan, R., (1980). Use of repetition to facilitate spontaneous language acquisition. Journal of Psycholinguistic Research 9 (3), 231-241.

[9] Couture, M., \& Tremblay, S. (2006). Exploring the characteristics of the visuo-spatial Hebb repetition effect. Memory \& Cognition, 34, 1720-1729.

[10] Cumming, N., Page, M., \& Norris, D. (2003). Testing a positional model of the Hebb effect. Memory, 11, $43-63$.

[11] Dornyei, Z., (2003). Attitudes, orientations, and motivations in language learning: Advances in theory, research, and applications. Blackwell Publishing, Oxford.

[12] Gardner, R.C., Smythe, P.C., Brunet, G.R. (1977). Intensive second language study: Effects on attitudes, motivation and French achievement. Language Learning 27, 243-261.

[13] Gardner, R. C. (2000). Correlation, causation, motivation, and second language acquisition. Canadian Psychology, 41, 10-24.

[14] Halliwell, S. (1992). Teaching English in the primary classroom. New York: Longman.

[15] Hebb, D. O. (1961). Brain mechanisms and learning. In J. F. Delafresnaye (Ed.), Distinctive features of learning in the higher animal. New York: Oxford University Press.

[16] Hitch, G. J., Fastame, M. C., \& Flude, B. (2005). How is the serial order of a verbal sequence coded? Some comparisons between models. Memory, 3-4, 247-258.

[17] Huang, C. (2010). Other-repetition in Mandarin child language: A discourse-pragmatic perspective. Journal of Pragmatics 42 , pp. 825-839

[18] Krashen, S. (1994). The pleasure hypothesis. In J. Alatis (Ed.), Georgetown University round table on language and linguistics, 299-322. Washingtion, DC: Georgetown University Press.

[19] Krashen, S.D. (1985). The Input Hypothesis Harlow: Longman.

[20] Krashen, S.D. (1987). Principles and Practice in Second Language Acquisition. Prentice-Hall International, Englewood Cliffs, NJ.

[21] Krashen, S. (1993b). The Power of Reading. Englewood, CO: Libraries Unlimited.

[22] Krashen, S. (2002c). Foreign Language Education, The Easy Way. Taipei: Crane Publishing Co.

[23] Kuczaj, Stan A. (1982). Language play and language acquisition. In: Reese, H.W. (Ed.), Advances in Child Development and Behaviour, vol. 17. Academic Press, New York, pp. 197-232.

[24] Lao, C. Y. and Krashen, S. (2000). The Impact of Popular Literature Study on Literacy Development in EFL: More Evidence for the Power of Reading. System, 28, 91-102.

[25] Larsen, Diane and Freeman. (2000).Techniques and Principles in Language Teaching. London: Oxford University Press.

[26] Manolopoulou-Sergi, E. (2004). Motivation within the information processing model of foreign language learning. System 32, 427-441.

[27] Mason, B., Krashen, S. (1997). Extensive reading in English as a foreign language. System 25, 91-102.

[28] McKelvie, S. J. (1987). Learning and awareness in the Hebb digits task. The Journal of General Psychology, 114, 75-88.

[29] Mihaljević Djigunović, J. (2006). Role of affective factors in the development of productive skills. In J. Horváth \& M. Nikolov (Eds.), UPRT 2007: Empirical studies in English applied linguistics (pp. 217-243). 
[30] Moerk, E., L. (1977). Processes and products of imitation: additional evidence that imitation is progressive. Journal of Psycholinguistic Research 6, 187-202.

[31] Pe'rez-Pereira, Miguel. (1994). Imitations, repetitions, routines, and the child's analysis of language: insights from the blind. Journal of Child Language 21, 317-337.

[32] Pinter, A. (2006). Teaching young language learners. Oxford: Oxford University Press.

[33] Rao, Z. (2002). Chinese Students' perceptions of Communicative and Non-communicative activities in EFL Classroom. System, $30,85-105$.

[34] Richards, J.C., \& Rodgers, T. (1986). Approaches and Methods in Language Teaching: A Description and Analysis. Cambridge University Press, Cambridge.

[35] Richards, J., and Rodgers, T. (2001). Approaches and methods in language teaching (2nd ed.). New York: Cambridge University Press.

[36] Ryan, R.M., \& Deci, E.L. (2000). Self-determination theory and the facilitation of intrinsic motivation, social development, and well-being. American Psychology, 55, 68-78.

[37] Sims, J. (1996). A comparative study of improvements in reading comprehension of skill based instruction and extensive reading for pleasure with Taiwanese freshman university students. Doctoral Dissertation. Florida State University: College of Education.

[38] Singh, M., \& Li, L. (2005). Communicative Language Teaching in China: Misconceptions, Applications and Perceptions. Australian Association for research in education

[39] Skinner, B., \& Madden, M. C. (2009). Help seeking in English language learning. ELT Journal, 64(1),21-31.

[40] Slatterly, M., \& Willis, J. (2001). English for primary teachers. Hong Kong: Oxford University Press.

[41] Snow, C. E., (1981). The uses of imitation. Journal of Child Language 8, 205-212.

[42] Snow, C. E., (1983). Saying it again: the role of expanded and deferred imitations in language acquisition. In: Nelson, K.E. (Ed.), Children's Language, vol. 4. Erlbaum, Hillsdale, NJ, pp. 29-58.

[43] Speidel, G. E., Nelson, K.E. (1989). The Many Faces of Imitation in Children. Springer-Verlag, New York.

[44] Speidel, Gisela E., Herreshoff, Madeleen J., (1989). Imitation and the construction of long utterances. In: Speidel, G.E., Nelson, K.E. (Eds.), The Many Faces of Imitation in Children. Springer-Verlag, New York, pp. 181-197.

[45] Stine, E., Bohannon, J. (1983). Imitations, interactions and language acquisition. Journal of Child Language 10, $589-603$.

[46] Tager-Flusberg, H., Calkins, S. (1990). Does imitation facilitate the acquisition of grammar? Evidence from a study of autistic, Down's syndrome and normal children. Journal of Child Language 17, 591-606.

[47] Thompson, G. (1996). Some Misconceptions about Communicative Language Teaching. ELT Journal, 50(1) 9-15.

[48] VanPatten, Bill \& Jessica Williams. (2007). Theories in Second Language Acquisition. New Jersey: Lawrence Erlbaum Associates.

[49] Weir, C. J. (1990) Communicative language testing. London: Prentice Hall.

[50] Widdowson, HG. (1978). Teaching Language as Communication. Oxford: Oxford University Press.

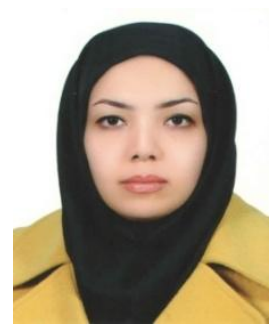

Afsaneh Rahimi Tehrani (1985, Isfahan, Iran) has an MA in English Language Teaching from university of Isfahan, Iran. She is currently teaching English in Azad university of Khoragan and has taught courses in general English as well as translation. She has also published a number of articles on discourse analysis, error correction, young learners' language learning, and English writing.

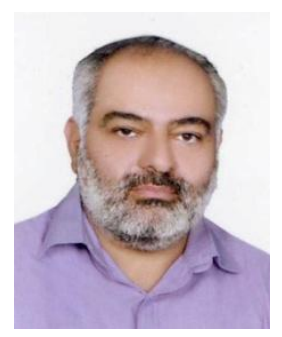

Hossein Barati is a member of the English department, University of Isfahan, where he is assistant Professor of Applied Linguistics. He has a PhD in 'Language Testing' from University of Bristol, England, and has been involved in research in language testing, programme evaluation, reading strategies, and classroom discourse. Before becoming a university lecturer in 1992, he was a language teacher at Ministry of Education, Isfahan, Iran. He has published in areas of language testing and assessment, and language programme evaluation. He was a member of a research project on Developing a new model of teaching English to adult non-English majors at University of Isfahan, funded by University of Isfahan.

$\mathrm{He}$ has also co-authored some publications on DIF in Iranian National University Entrance Exam (INUEE), 2007; Linguistic constraints and language teaching, 2008; and Cultural differences in EFL performance on cloze tests, 2010. Further a text-book A step forward in English for intermediate EFL learners is among his latest publications.

Hossein is currently working on topics such as 'Teaching English to Iranian young learners, 'Collaborative teaching: Revisiting the methodology of teaching English to secondary school students in Isfahan', and 'The consequential validity of high stakes tests in the Iranian context'.

Manijeh Youhanaee holds a PhD in language and linguistics from the University of Essex. She has co-authored with Badrizadeh "A Descriptive Dictionary of Theories of Generative Grammar". She has published a number of articles on the teaching/ acquisition 
of different English syntactic properties by native speakers of Persian. She teaches MA and PhD courses in linguistics, generative grammar, TEFL and SLA. Her areas of interest include syntactic theory, acquisition of L2 \& L3 syntax and issues in teaching and learning English as a second/foreign language. 